\title{
Poverty, race, and children's progress at school in South Africa
}

\author{
Ian M. Timæusa, Sandile Simelane ${ }^{b}$ and Thabo Letsoaloc \\ ${ }^{a}$ Centre for Population Studies, London School of Hygiene \& Tropical Medicine \\ ${ }^{b}$ Information Analysis Unit, Development Bank of Southern Africa \\ c Programmes Office, Statistics South Africa
}

Correspondence to: Professor Ian Timæus, Centre for Population Studies, London School of Hygiene \& Tropical Medicine, Keppel Street, London, WC1E 7HT, UK. Ian.Timaeus@lshtm.ac.uk.Tel:020-72994689.
Abstract:
96 words
Body:
6859 words

\section{Acknowledgements}

At the time that this research was conducted, SS and TL were based at the School of Development Studies, University of KwaZulu-Natal. We thank Julian May, Tom Moultrie, and Nompu Nzimande for their valuable advice and feedback during the development of this paper. The research was supported by the Programme to Support Pro-poor Policy Development (PSPPD), a partnership project of the Presidency of South Africa and the European Union, and the National Research Foundation through the South African Research Chair in Applied Poverty Reduction Assessment. The authors are solely responsible for its contents, which can in no circumstances be regarded as reflecting the position of their employers, the European Union, or the Government of South Africa. 


\title{
Poverty, race, and children's progress at school in South Africa
}

\author{
ABSTRACT This article investigates inequalities in school attainment in South Africa using \\ community-based data collected in 2008 by the National Income Dynamics Study. Schools-based \\ research has concluded that poor children, who are mostly African, remain disadvantaged by the \\ continuing low performance of former African schools. In contrast, this analysis finds that most \\ educational disadvantages of African children, including their low matriculation rates, are accounted \\ for by household poverty and their mothers' own limited education. Thus, earlier studies may not \\ have adjusted fully for pupils' backgrounds or the performance of former African schools may have \\ improved since 2000.
}

\section{Introduction}

Education is widely recognised as both an integral component and an indicator of human development in general and children's wellbeing in particular. These two dimensions of the importance of education are clearly demonstrated in the conceptualisation and measurement of the human development index (HDI) by the United Nations Development Program (1990) and the United Nations' millennium development goal (MDG) on universal primary education.

One of the key components of the apartheid system in South Africa was its segregated educational system. Verwoerd as Minister for Native Affairs in the 1950s notoriously argued 'What is the use of teaching the Bantu child mathematics when it cannot use it in practice? That is quite absurd. Education must train people in accordance with their opportunities in life, according to the sphere in which they live' (quoted, for example, in Clark and Worger, 2004). Not only were there separate schools for each population group, but different systems existed in the core of the country and each of the so-called 'homelands' and 'independent states' (Fiske and Ladd, 2005; Case and Deaton, 1999; Thomas, 1996). This fragmented system was characterised by racially-biased public (and private) expenditure on education and large differences in the quality of education received by different racial groups, with non-white children getting the raw deal while their white counterparts enjoyed a high-quality education. Although differentials in expenditure on the schooling of the different racial groups shrank somewhat over time, nonwhite schools remained both severely under-resourced and hampered by deliberately-fostered institutionalised weaknesses until the apartheid system was dismantled entirely.

Since the collapse of apartheid regime, the importance of education as a foundation for broad-based human and socioeconomic development has been articulated in South Africa in a 
number of ways. The bill of rights in the country's constitution prescribes that every citizen has a right to basic education, including adult basic education and further education (Republic of South Africa, 1996). Moreover, the country's overarching socioeconomic policy framework has viewed education as an important mechanism through which inequities that were inherited from the apartheid era could be addressed (African National Congress, 1994). The new government rapidly integrated the separate schooling systems for the different races and homelands into a single system with a unified resource-allocation mechanism and pay structure for teachers. The operation of schools became the responsibility of provinces. The Schools Act, 1996, made schooling compulsory for all children aged seven to 15 years (Republic of South Africa, 1996). Moreover, education has been among the main priority areas of government since 1994 and has accounted for substantial proportions of the country's gross domestic product and overall state spending. For example, of every Rand spent by the South African government between 2007 and 2011, about 20 cents went to education (Republic of South Africa, 2011).

Despite the importance accorded to education in the South African government's policy statements and budget allocations, the school system remains to some extent a prisoner of its past. Many schools operate in inadequate buildings and a significant minority of rural schools still lack electricity connections, phone lines or running water. Moreover, many older African teachers received a very poor training in apartheid-era colleges, but it has proved difficult to establish professional development programmes that win the support of the entire teaching profession and effectively address the inadequate skills of some teachers. At the other end of the spectrum, about 3 per cent of children attend independent schools (Republic of South Africa, 2010) and these typically have considerably more favourable staff-pupil ratios and better facilities than public schools. In addition, although the government quickly eliminated most inequities in the allocation of its own resources to schools, it has also been concerned to prevent the middle classes opting out the public schooling system. Thus, it allows public schools to raise supplementary income from parents by means of fees and other charges. Formerly White, 'Model C' schools, in particular, often do so on a sufficiently large scale to allow them, for example, to employ additional teachers. Thus, comparative research indicates that variation between schools, as opposed to at the individual level, in the reading and mathematical skills of children completing primary school in South Africa is extreme (van der Berg, 2008).

A broad consensus exists among educationalists and education researchers in South Africa that, while the country rapidly established a colour-blind schooling system that treats all races as equal and eliminated gross inequalities in the allocation of resources, the quality of many children's schooling in South Africa has remained low and progress toward securing more 
equitable outcomes has been limited (Nelson Mandela Foundation, 2004; Fiske and Ladd, 2005; Taylor et al., 2008). The modest body of quantitative evidence regarding the determinants of schooling outcomes in post-apartheid South Africa tends to support this view (for example, van der Berg, 2007, 2008; Bhorat and Oosthuizen, 2009), although an initial look at the 2008 data that are analysed in this paper found somewhat higher levels of attainment and smaller racial differences in younger than older cohorts of children (Branson and Lam, 2010).

The central message emerging from the quantitative analyses of schools-based datasets is that differences in educational outcomes between schools in South Africa remain huge in comparison with most countries. The attainment of students at former African schools is markedly worse than that of students at former Coloured and Indian schools, while students at these schools do far less well than those at former White schools. Moreover, differences in outcomes between former African schools are also huge, with some ex-homeland schools performing relatively well (Bhorat and Oosthuizen, 2009). While both certain indicators of educational inputs, such as teacher-pupil ratios, the physical environment or the equipment available in schools, and certain socioeconomic characteristics of schools' intakes or catchment areas have an effect on educational outcomes, they explain little of the differential performance of schools. Instead, the evidence suggests, these differences result in part from historicallyrooted characteristics of schools that are difficult to measure explicitly, such as the ability and motivation of the teaching staff and managerial skills of principals. Second, they probably reflect unmeasured characteristics of children's parents or other carers, most notably the importance they assign to children's education.

Almost all this earlier research on schooling outcomes in South Africa has analysed school-based datasets and surveys. These datasets either lack individual-level information on the socioeconomic and demographic backgrounds of the children attending the schools or obtained this information by asking children in school about their domestic circumstances or getting them to deliver questionnaires to their parents for self-completion. School-based datasets provide rich data on children's schools and, in some cases, on children's educational achievements, but limited data on their home backgrounds. In particular, while some school-based surveys have collected enough information to construct an asset-based indicator of the socioeconomic status of the child's household, none that we are aware of have collected sufficiently detailed information, including detailed household expenditure data, to control fully for socioeconomic status. Thus, it remains unclear to what extent poverty continues to hold back children's progress at school in South Africa and how the effects of socioeconomic status, race, and locale interrelate. 
This article investigates inequalities in children's educational attainment in South Africa using 2008 data collected by the National Income Dynamics Study (NIDS). This new nationallyrepresentative, community-based study has collected detailed current status and retrospective data on the attainment of school-age children and young adults. It has also collected detailed information on the demographic and socioeconomic characteristics of their households. Thus, it is a powerful tool for the investigation of the influence of children's home background on their progress at school and, in particular, the interrelated effects of socioeconomic status, race and locale. Using NIDS, moreover, one can study for the first time cohorts of children who experienced their entire schooling after the collapse of apartheid.

\section{Data, outcomes, and methods}

NIDS is the first nationally-representative household panel study to be mounted in South Africa. It is funded by the South African Presidency in order to monitor and investigate poverty in the country and run by the Southern African Labour and Development Research Unit at the University of Cape Town. The baseline wave of NIDS in 2008 conducted interviews on 7305 households and collected data on more than 28,000 people (Leibbrandt et al., 2009).

The study collects basic demographic data on all household members; information on their dwelling and access to utilities; and detailed income and expenditure data. It also collects information on social grants, demographic events in the households, household members' health, including anthropometric measures, and other topics. In particular, it collects detailed data on the enrolment in school, progress and outcomes of school-age children and young adults. Thus, NIDS is a new and important resource for the study of inequalities in child welfare and the determinants of children's educational attainment in South Africa.

The straightforward data on enrolment in an educational institution and highest grade achieved collected in the baseline wave of NIDS agree fairly closely with the results of other recent national inquiries in South Africa such as the 2007 Community and Labour Force surveys (Branson and Lam, 2009). However, NIDS is already a richer source of educational data than these other community-based inquiries even though only the first wave of the data was available at the time of writing. First, it collected detailed retrospective information from everyone aged 30 or less who had ever attended school on their age at first enrolment and history of grade repetition. Second, the study has measured households' economic position in greater detail than other national inquiries.

Nearly all children in South Africa today now remain enrolled in school until the legal school leaving age (Anderson et al., 2001; Motala et al., 2007; Republic of South Africa, 2008, 
2009; Lam et al., 2010) and so enrolment is a less important indicator of the adequacy of the schooling system than in many low- and middle-income countries. On the other hand, late enrolment in Grade 1 remains a problem, particularly among African children (Motala et al., 2007; Lam et al., 2010).

Limited routine data on children's educational achievements (schooling outputs as opposed to inputs) exist in South Africa in advance of them taking the matriculation examination at the end of their schooling. While a few school-based research studies have tested younger children successfully (for example, Moloi and Chetty, 2010), attempts to measure literacy and numeracy in household surveys have had limited success. The problem stems in part from the huge variation between population groups in how adults and children customarily interact, teaching methods used in schools, and language background. Even if testing is conducted in several languages, some children are tested in their home language and some in a second language. Thus, Lam et al. (2008) recommend that comparisons of literacy and numeracy test scores across different population groups should be intepreted with caution.

The baseline wave of NIDS did no better than previous South African household surveys at measuring literacy and numeracy in that it only succeeded at testing 41 per cent of the teenagers aged 12 to 19 who participated in the study. Therefore, this paper focuses on NIDS' main strength as a data source for the study of inequalities in schooling outcomes, which is the rich series of questions asked about grade progression and repetition. Grade repetition is common in South Africa and is more pronounced among African learners (Anderson et al., 2001; Motala et al., 2007; Branson and Lam, 2009; Lam et al., 2010), though the proportion of children affected has dropped by about a third since 2000 (Hungi, 2010). Of course, measures of children's attainment may be linked only loosely to the level of skills and knowledge that they acquire at school. Moreover, Lam et al. (2010) find that, in the Cape Town area, the grade advancement of African children is, to a worrying extent, a 'lottery'. Nevertheless, grade repetition is undeniably a direct measure of unsatisfactory educational attainment that reflects children's learning outcomes as assessed by their teachers. Moreover, as it is often a precursor to children failing to complete their schooling, it is a major problem in South Africa in its own right.

Thus, the outcome measures on which this article focuses are whether or not children and young people born in 1989-2001 first enrolled in primary school on time (that is by the calendar year in which they had their seventh birthday), whether these children had ever repeated a grade at school, and whether or not they had repeated two or more grades. In addition, we examined matriculation rates among young adults. However, to reduce the likelihood that any 
relationship between matriculating and household socioeconomic status arises because young adults who have matriculated contribute more to their household's income than those who have not, the regression analysis of differential matriculation was restricted to people who were still living with a parent or other relative in an older generation and who did not have paid work. According to NIDS, this subset of young adults constitutes 48 per cent of the population aged 19 to 29 , dropping from about 67 per cent of the population aged 19 to 21 to only about 28 per cent of people in their late-20s.

The analysis incorporates four different indicators of the socioeconomic status of households. The first is money-metric income as measured by detailed questions on households' expenditures on a lengthy series of food and non-food items. Because no agreed equivalence scale exists for South Africa, the index used was the household's total expenditure per resident member (excluding actual and imputed rents). Second, we constructed an index of how well people were housed by applying a principal components analysis to seven binary measures of: housing type (modern compared with traditional and informal), water source (piped and borehole compared with all others) and whether it is onsite, type of toilet (flush compared with others), materials used to construct the roof (concrete, tiles, and corrugated metal or asbestos sheeting compared with others) and the walls (bricks, cement blocks, concrete compared with others), and whether the household has an electricity connection. This index fails to discriminate between the top 35 per cent of households, who all live in modern, well-constructed, fullyserviced households. Third, we constructed a similar index of the durables owned by the household based on nine assets: a motor vehicle, lounge suite, fridge or fridge-freezer, washing machine, microwave oven, television, video player, and stereo, CD or MP3 player. This index does not discriminate among the 25 per cent of households who own none of these assets. Lastly, we compared households where children sometimes or frequently went to bed hungry because of a lack of food in the household with households where this seldom or never occurred. This indicator has been proposed as a simple but powerful measure of food insufficiency that correlates well with money-metric poverty as measured by a much lengthier series of questions (for example, Faye et al., 2011).

The school year in South Africa starts in January and measurement of children's progress at school requires the best possible estimates of children's year of birth. Therefore, missing dates of birth from the individual and roster questionnaires were replaced with those from the children's mother's birth histories where these were available. Then the missing dates of birth for 200 children whose age at interview had been reported on the household roster were imputed 
stochastically using the exact date when the household was interviewed to assign the correct proportions of them to each of two calendar years in which they might have been born.

No information was available on the highest educational attainment of the mothers of some 13 per cent of the children whose educational progress is analysed here. As this characteristic is an important confounder of socioeconomic status, these missing values were imputed by predicting the probability that the mother belonged in each educational category using an ordered logistic regression model that included all the variables used in the subsequent analysis together with information on whether the mother remained alive and whether she was a member of the same household as the child in question.

All the educational outcomes examined here are binary variables and were modelled using logistic regression. The regression coefficients and their standard errors have been adjusted for the fact that NIDS uses a weighted, stratified, and clustered sample design.

The final set of regression models presented are cluster fixed effects models that restrict the comparisons of each child's educational attainment to those with other children living in the same small geographical area. The aim of these models is to control for unmeasured supply-side factors that may be correlated with and bias the estimated impact of household-level determinants of children's educational outcomes. In particular, while these models do not standardise for the quality of the schooling that the children receive, they do control for variations between places in the characteristics of the schools accessible to the households in the study (conditional on their ability to pay the costs involved).

\section{Results}

Table 1 presents a few statistics from NIDS describing the socioeconomic and demographic characteristics of children born in 1989-2001. Poor people in South Africa live in much larger households than the better-off and, as a result, 40 per cent of children live in the 20 per cent of households with the lowest expenditure per member and only 9 per cent of children in the bestoff 20 per cent of households. As one would expect, the quality of children's housing and ownership of consumer durables by their households in strongly associated with households' expenditure. More than a fifth of children live in households where they are reported to go to bed hungry sometimes or frequently, as opposed to rarely or never, and this proportion rises to nearly a third of children in the bottom expenditure quintile. While 86 per cent of school-age children are African, the majority of children in households in the highest expenditure quintile are not. Almost no children from the three numerically smaller racial groups (Coloured, Indian and White) belong to households in the lowest expenditure quintile. School-age children are 
divided more-or-less equally between rural and urban areas but nearly all the children in the most affluent fifth of households live in urban areas.

Table 2 examines school enrolment by age according to NIDS and to the Living Standards and Development Survey, a nationally-representative household survey conducted in 1993 (PSLSD, 1994). A significant minority of school-age children were not in school in 1993 but, by 2008, late enrolment had become far less common and more than 95 per cent of children were remaining in school till the statutory school-leaving age (the end of the year in which children become 16). Looking at the proportion of those aged 19 to 21 years remaining enrolled in school, a slight drop occurred over the 15 -year period. This probably reflects an increase in the proportion of young people who were completing their schooling on time.

Table 3 presents further indicators of progress at school for different birth cohorts of children based on retrospective reports of their educational histories. These reports also suggest that late enrolment in school was far less of a problem in 2008 than the early 1990s. However, these results need interpreting cautiously as NIDS failed to obtain this information successfully for some 23 per cent of children and young people (rising from 1 per cent of those born in 2000, to 27 per cent of those born in 1995, and 36 per cent of those born in 1990). Bearing this in mind, the late enrolment rate seems to have hovered at around 20 per cent between the mid1990s and mid-2000s before declining sharply in the three years up to the time of fieldwork.

The cohort differences in grade repetition among children who had ever-enrolled in school cannot be interpreted as indicative of trends over time as they largely reflect the fact that the longer a child has been at school the more likely (s)he is to have been required to repeat a grade. The proportion of children having repeated one grade leaps up between Grade 3 and Grade 4, and then rises sharply again to about 50 per cent among children who were in the final years of their schooling in 2008. The proportion of children having repeated two or more grades rises more steadily with age, reaching about 20 per cent among those who were completing their schooling in 2008.

The final column of Table 3 can be taken as indicative of trends and suggests that about 44 per cent of young adults had matriculated, with little improvement in this proportion over time among those aged 21 to 29 in 2008. These ages approximately represent students matriculating during the decade up to 2005 and are in fairly close agreement with those from other sources. According to these figures, less than half the young people who eventually matriculated successfully, did so on time.

Table 4 presents logistic regression models that examine how the odds of children or young people progressing satisfactorily at school were related to where they were living and their 
demographic characteristics (birth cohort, sex and race), controlling for each of the other factors in the model. It should be noted that province and type of place of residence were measured in 2008, not at the time that the child enrolled, repeated a grade at school, or (in the case of the young adults) left school. These results suggest three clear-cut conclusions. First, educational attainment was far worse in rural areas than urban ones. Second, Africans did worse at school than South Africa's numerically smaller racial groups (Coloured, Indian, and White). Moreover, although the number of children from each of these groups in NIDS is too small to demonstrate this definitively, Coloured children seem to have been doing less well than Indian and White children. Third, girls not only progressed better at school than boys and were more likely to have passed their matriculation examination $(P=0.069)$, but were significantly more likely than boys to have been enrolled by their parents at the correct age.

Table 5 presents a second set of logistic regression models. These models control in addition for the educational attainment of the child's or young person's mother, for the household's wealth as measured by the housing quality and consumer durable indices, for household expenditure per head, and for the summary indicator of food insufficiency. The most striking finding from this analysis is that, even after controlling for where children were living, for their demographic characteristics and for the socioeconomic status of their households, the children of women who were educated themselves were doing very much better at school than the children of uneducated women. At the extreme, more than threefold differences existed in the odds of enrolling in school at the appropriate age and in the odds of matriculating between the children of women who had matriculated themselves and the children of women who had little or no schooling and were probably illiterate $(P<0.001)$.

Table 5 also shows that, as expected, children from relatively well-off households were doing better at school than those from poorer households. Which of the wealth and income indicators shows up as most important differs between the educational outcomes. Socioeconomic status had most influence on the eventual outcome of children's schooling, with not only very large differentials in matriculation according to money-metric expenditure but further differentiation in this outcome according to the other socioeconomic indicators. The quadratic term on expenditure implies that each doubling of household income produced a larger and larger rise in the odds that children would matriculate successfully.

As one might expect, the better progress at school of girls is unaffected by controlling for these familial and socioeconomic variables. In contrast, Table 5 suggests that mother's education and socioeconomic status largely accounted for the superior attainment of children living in urban areas and children from the smaller racial groups. Moreover, late enrolment was 
associated more strongly with household wealth in the form of consumer durables in rural areas (odds ratio $0.53, P<0.001$ ) than urban ones (odds ratio $0.90, P=0.029$ ). Thus, while in general late enrolment remained more common in rural areas even after stratifying by mother's education and socioeconomic status, relatively wealthy rural households were more likely than urban households to enrol their children in school on time.

After taking into account their more privileged home backgrounds, White children were less likely to start school on time than black African children and black Africans were more than twice as likely to matriculate successfully from school as young people of a similar socioeconomic status from the three other racial groups combined (odds ratio 2.6, $P=0.003$; full results for this model not shown). On the other hand, it is clear that African children remained more likely to have had to repeat one grade at school than other children even after controlling for their socioeconomic disadvantages. However, this educational disadvantage did not extend to their chances of repeating two or more grades. Moreover, if one looks separately at inequalities in grade repetition in primary and secondary school (results not shown), one finds that the relatively low rates of grade repetition of Coloured children and the low rates of grade repetition in the Western Cape and Gauteng were concentrated in the primary school years. On the other hand, there is some suggestion $(P=0.065)$ that repeating grades in secondary school was less common in urban than rural areas.

If anything, the characteristics of the populations of the different provinces were masking, rather than accounting for, inter-provincial differences in children's progress at school. Late enrolment was particularly common in Northern Cape and relatively rare in Limpopo. Grade repetition was more common in Free State, KwaZulu-Natal and Mpumalanga than in the three Cape provinces and Gauteng. After allowing for the composition of the population, the odds of matriculating were lowest in Gauteng, on the one hand, and the two most deprived provinces, Eastern Cape and Limpopo, on the other.

Table 6 presents the cluster fixed effects models, which control for unmeasured variation between places in the accessibility and quality of the schools in the area. The samples of children are somewhat smaller than in Tables 4 and 5 as children living in clusters where either all or none of them had experienced the outcome in question contribute nothing to the analysis. The overall impression one obtains from comparing tables 4 and 5 is that stratifying the analysis by the cluster in which children live makes little difference to the results. Notably, the coefficients on the various socioeconomic indicators differ hardly at all. However, the coefficients for population group vary somewhat. For example, the late enrolment of White children apparent in estimates in Table 5 turns out to be a product of the types of place in which they live. The 
instability in these coefficients is unsurprising given the small sample of children from each of the racial groups other than black Africans and the high degree of residential segregation that persists in South Africa. However, apart from the frequency with which they are required to repeat a single grade, neither the models in Table 5 nor those in Table 6 provide any evidence that Africans' attainment at school is worse than that of other children after controlling for their socioeconomic backgrounds and mothers' education.

\section{Discussion}

The baseline wave of NIDS shows that in 2008 nearly all children aged seven to 15 years old were enrolled in school, and that no significant differences existed between boys and girls in enrolment. The picture painted by these data marks a significant improvement from the situation in 1993, when a significant proportion of primary-school-age children were not enrolled in school. NIDS shows that South Africa is close to achieving MDG2 and the education-for-all goal of universal primary education.

Of course, encouraging as the NIDS results may be with regard to access to schooling, the fact that any school-age children were not attending an educational institution should be of concern. This is all the more so in the context of the education policies that are currently in place in South Africa, including the no-school-fee policy implemented for schools in poor districts since 2007 (Republic of South Africa, 2009). While it may be hoped that this policy will reduce the number of dropouts in future, it did not succeed immediately in attracting into school children who were not enrolled. Thus, those children who are still not enrolled may be being kept out of school for other than financial reasons.

Despite the progress that has been made in improving access to school among South African children, this analysis shows that the country is still facing serious challenges with regards to the effectiveness of its schooling system. The matriculation rate, which represents a summary indicator of children's learning during their school career as well as being of vital importance to their career prospects, only improved marginally during the decade leading up to 2008. Moreover, substantial social and economic differentials still persist in children's educational attainment. These differentials mirror those that were observed before 1994. In particular, NIDS reveals that African children were still progressing less well at school than children from the numerically-smaller racial groups in 2008 and that children in rural areas were doing less well than those from the towns. These findings are in line with conclusions drawn from previous national, provincial and localised inquiries (for example, Anderson et al., 2001 using the 1995 October Household Survey data; Timæus and Boler, 2007 - using the KwaZuluNatal Income Dynamics Study; and Lam et al., 2010 - using the Cape Area Panel Study). 
When one controls for family background, it becomes apparent that it is this that accounts for the lower attainment of African and rural children. Although African children remained more likely to repeat a grade at school than children from other racial groups, over that part of the socioeconomic hierarchy in which other racial groups were represented they were, if anything, more likely to have matriculated successfully than other children from similar backgrounds. However, given that this finding is based only on those young people who had not progressed to employment or established their own household, we wish to emphasize only that there is no evidence that African children remained disadvantaged by that characteristic in itself. Moreover, this was the case even though most young adults in 2008 began school before the collapse of the apartheid regime and its segregated educational system. This finding is consistent with results obtained from Cape Area Panel Study (Lam et al., 2010). It represents an encouraging sign that the component of racial disadvantage in education that can be ascribed to institutionalised racism rather than socioeconomic factors has been largely addressed in South African schools.

Nevertheless, Africans may remain disadvantaged in the job market compared with other young people with the same educational qualifications. This could occur either if they have a portfolio of subject-specific skills that are less attractive to employers than those of other racial groups, notably lower levels of achievement at mathematics, if they acquire fewer generic employment-related skills in school and at home than Coloured, Indian and White children, or if the impact of negative discrimination by some employers continues to outweigh the impact of positive discrimination by others.

What the results emphasize is that children raised in poor households, who are mostly African, experienced major educational disadvantages compared with their counterparts from better-off households, who are drawn from all population groups, according to both incomeand wealth-based indicators. Even after controlling for their place of residence and other covariates, children from richer households were more likely to have enrolled in school on time, progressed better through school, and were much more likely to have matriculated than children from poor households. Other studies have also found that that household poverty has a huge and statistically significant impact on child schooling outcomes in South Africa (for example, Anderson et al., 2001; Timæus and Boler, 2007; Lam et al., 2010).

Historically, a positive association has existed in South Africa between the quality of schools in a neighbourhood and the average socioeconomic status of households in that neighbourhood (van der Berg and Louw, 2006). The cluster fixed effects models partly address the limitation of NIDS that it lacks measures of school quality. However, these models yielded 
similar results to the models that did not control for locale. The most obvious explanation of this finding is that characteristics of schools that impact on educational outcomes are not associated with the socioeconomic characteristics of the households in their catchment areas. This is not to suggest either that the quality of schools is unimportant for children's attainment or that all schools are now equally effective. The finding is consistent, however, with the view that weak schools are no longer concentrated in rural areas or in poorer urban communities. Instead, socioeconomic inequalities in educational attainment may originate entirely in the characteristics of the children's households themselves.

Even though familial factors are undoubtedly crucial for children's success at school, it is somewhat counterintuitive that the multiple, manifest differences between the schools typically attended by middle-class and poor South Africans are irrelevant to educational attainment. Thus, another reason why the coefficients on the socioeconomic variables did not attenuate in the fixed effects models may be that, as van der Berg (2008) found, better-off children benefit more from attending better schools than poor children. Unfortunately, one cannot investigate this possibility further without access to explicit measures of the quality of schools.

The fixed effects models do not allow, moreover, for the fact that children may not have been enrolled in the school closest to their homes. Indeed, children sometimes commute a considerable distance to attend a preferred school, a phenomena that has become increasingly prevalent in post-apartheid South Africa (Lemon and Battersby-Lennard, 2010). The fixed effects models divided children into groups living in the same locale with access to the same schools, rather than stratifying the analysis by the schools that children were actually attending. Thus, a further mechanism by which socioeconomic factors may have influenced attainment is that highly-motivated and affluent parents may be more likely than their neighbours to send their children to high-quality schools even if that involves a lengthy daily journey and additional expense.

A third reason why the fixed effects models provided no evidence that our estimates of the effects of home background are confounded by variations in school quality may be that parents' socioeconomic status has become a major driver of the variations in school quality that are manifest in South Africa. On the one hand, better-off parents may encourage schools to charge higher fees and provide other resources, which in turn may attract high-calibre staff to these schools. On the other hand, better-off parents may be more likely than poorer ones to intervene to ensure that principals and teachers attend to their duties conscientiously, for example by complaining if their children are not set homework or it is not marked properly. 
Research using school-based datasets has suggested that an important reason why the educational attainment of poor children is less satisfactory than that of other children is that most of them attend former African schools and that these schools perform less well than other schools for reasons rooted in South Africa's past (van der Berg, 2007, 2008; Bhorat and Oosthuizen, 2009). The present study, however, suggests that, while this may explain why so many African children had repeated at least one grade, it was less important for outcomes of more enduring significance. Instead, the socioeconomic and demographic backgrounds of children from different racial groups fully accounted for the differences between the groups in children's educational attainment. For example, while White children remained far more likely than other children to matriculate, this reflected their privileged backgrounds. No evidence exists that they were still attending better schools than children from the other racial groups of the same socioeconomic status and with equally educated mothers. Both the fact that racial group dropped out of significance once controls for socioeconomic factors were introduced in Table 5 and the similarity of the pattern of socioeconomic differentials identified by the logistic regression models in Table 5 and the cluster fixed effects models in Table 6 argue against the idea that unmeasured characteristics of schools remain responsible for differences in attainment between the racial groups.

A recently published paper, which was also based on NIDS, obtained similar results (Branson and Lam, 2010). It found that, although adjusting for school quality (proxied by school fees) attenuates racial differences in school-grade repetition, the school quality variable ends up statistically insignificant when controls for other household characteristics are added to the regression model of grade repetition.

Two of the studies that found that the poorest children, who are overwhelmingly African, have remained disadvantaged in the post-apartheid period by the continuing low performance of former African schools were based on the analysis of the results of reading and mathematics tests administered to children in their last year of primary school (van der Berg, $2007,2008)$. Thus, one reason why the findings presented here appear inconsistent with those of these earlier studies may be that this study has examined a different set of outcome variables. In addition, both these two earlier studies and a third one, which did look at matriculation rates (Bhorat and Oosthuizen, 2009), were based on data from around 2000. Thus, our results might also indicate that the South African government has succeeded since then in addressing the systematic weaknesses of rural schools and schools catering for the urban poor. Finally, the earlier studies may have overestimated the role played by inadequate teaching and weak 
leadership in accounting for the poor test results of the least successful schools because they were unable to adjust fully for the adverse family circumstances of pupils attending such schools.

The present study shows that maternal education mattered a lot for whether or not children enrolled for school at the appropriate age and for whether or not they went on to matriculate. The effect persisted in the cluster fixed effects models. Therefore, it is unlikely that the mechanism accounting for it is that educated parents move to areas with good schools. However, as we suggested with respect to better-off households, as well as supporting their children in their studies, they may be more willing than other parents to enrol their children in schools a long way from their homes in order to try and secure them a better education. In addition, the apparent impact of mothers' education will be inflated if it is positively correlated with their children's ability as well as influencing their application to their studies (van der Berg and Louw, 2006). It is impossible to disentangle the importance of these different processes using NIDS data, but it is unlikely that confounding with ability accounts fully for effects of the size shown in Table 5. Thus, it seems fairly clear that educated mothers are more committed to their children's education than uneducated mothers and that, even after controlling for the resources available to the household, this commitment substantially benefited their children's progress at school.

Marked differences existed between the provinces in important aspects of children's schooling such as whether they enrolled on time, whether they had been required to repeat grades, and whether they eventually matriculated successfully. These interprovincial differences were not explained by the characteristics of the pupils and their families. Thus, even if there has been some evening out of variations in school quality within provinces, certain provinces still have more effective schooling systems than others. In particular, the proportion of children matriculating successfully was markedly lower than it should be in Eastern Cape, Limpopo and Gauteng, given the characteristics of school children in these provinces. It seems likely that in the first two provinces this reflects systemic and managerial weaknesses in the schooling system but in Gauteng other factors, such as competing opportunities or distractions for older children, may also militate against matriculation.

Finally, like previous studies (for example, Anderson, 2000; Timæus and Boler, 2007; Lam et al., 2010), our results revealed that the attainment of boys is substantially worse than that of girls in South Africa. Moreover, the fact that boys were significantly less likely than girls to be enrolled in school at the appropriate age suggests that the problem is not just one of peer pressure or the behaviour of educators but is at least in part due to the attitudes and prejudices of parents. 
In conclusion, 15 years after the collapse of the apartheid system huge inequalities still existed in children's educational attainment in South Africa with about half of them failing to matriculate. African children continued to have worse educational outcomes than other children but this was because most poor children are African. The evidence no longer suggests that the attainment of African children is worse than that of children with a similar background from other racial groups. One achievement of the post-apartheid period in South Africa is that race in itself is no longer a constraint on how well children are educated. One failure is that so little has been done to make poverty less of a constraint on children's educational attainment. 


\section{References}

African National Congress (1994) The Reconstruction and Development Programme: A Policy Framework (Johannesburg: Umnyango Publications).

Anderson, K. G., Case, A., and Lam, D. (2001) Causes and consequences of schooling outcomes in South Africa: evidence from survey data. Social Dynamics, 27(1), pp. 37-59.

Anderson, K. G. (2000) Family Structure, Parental Investment, and Educational Outcomes among Black South Africans. PSC Research Report No. 00-461, Population Studies Center, University of Michigan.

Bhorat, H and Oosthuizen, M. (2009) Determinants of Grade 12 pass rates in the postApartheid South African schooling system. Journal of African Economics, 18(4), pp. 634-666.

Branson, N. and Lam, D. (2009) Education: Analysis of the NIDS Wave 1 Dataset. NIDS Discussion Paper No. 3, Southern Africa Labour and Development Research Unit, University of Cape Town.

Branson, N. and Lam, D. (2010) Education inequality in South Africa: Evidence from the National Income Dynamics Study. Studies in Economics and Econometrics, 34(3), pp. 85-105.

Case, A. and Deaton, A. (1999) School inputs and educational outcomes in South Africa. The Quarterly Journal of Economics, 114(3), pp. 1047-1084.

Clark, N. L. and Worger, H. (2004) South Africa - The Rise and Fall of Apartheid (Harlow: Pearson Education).

Faye O., Baschieri A., Falkingham J., Muindi K. (2011) Hunger and food insecurity in Nairobi's Slums: an assessment using IRT Models. Journal of Urban Health, 88(Suppl 2), pp. 235-255.

Fiske, E. B. and Ladd, H. F. (2005) Racial Equality in Education: How Far Has South Africa Come? Working Paper Series SAN05-03, Terry Stanford Institute of Public Policy, Duke University.

Hungi, N. (2010) What are the Levels and Trends in Grade Repetition? SACMEQ Policy Issues Series, No. 5, Southern and Eastern Africa Consortium for Monitoring Educational Quality. http://www.sacmeq.org/downloads/policy/005-SACMEQPolicyIssuesSeries-

Graderepetition.pdf (accessed 16 January 2012)

Lam, D., Ardington, C., Branson, N., Case, A., Leibbrandt, M., Menendez, A., Seekings, J. and Sparks, M. (2008) The Cape Area Panel Study: Overview and Technical Documentation Waves 1-23-4 (2002-2006), Southern Africa Labour and Development Research Unit, University of Cape Town. 
Lam, D., Ardington, C. and Leibbrandt, M. (2011) Schooling as a lottery: racial differences in school advancement in urban South Africa. Journal of Development Economics, 95(2), pp. 121-136.

Leibbrandt, M., Woolard, I. and de Villier, L. (2009) Methodology: Report on NIDS Wave 1. NIDS Technical Paper No. 1, Southern Africa Labour and Development Research Unit, University of Cape Town.

Lemon, A., and Battersby-Lennard, J. (2010) Studying together, living apart: emerging geographies of school attendance in post-apartheid Cape Town. African Affairs, 110(438), pp. $97-120$.

Motala, S., Dieltiens, V., Carrim, N., Kgobe, P., Moyo, G. and Rembe, S. (2007) Educational Access in South Africa (Brighton, UK: Consortium for Research on Education, Access, Transitions and Equity).

Moloi, M. Q. and Chetty, M. (2010) The SACMEQ III Project in South Africa: A Study of the Conditions of Schooling and the Quality of Education (Pretoria: Department of Basic Education, Republic of South Africa).

PSLSD (1994) Project for Statistics on Living Standards and Development: South Africans rich and poor: Baseline bousehold statistics, South African Labour and Development Research Unit, University of Cape Town.

Republic of South Africa (1996) The South African Schools Act (Act no.84 of 1996) (Pretoria: Government Printers).

Republic of South Africa, Department of Basic Education (2010) Education Statistics in South Africa 2009 (Pretoria: Department of Basic Education, Republic of South Africa).

Republic of South Africa, Department of Education (2008) Education for All (EFA) - Country report South Africa (Pretoria: Department of Education, Republic of South Africa).

Republic of South Africa, Department of Education (2009) Trends in Education Macro Indicators: South Africa (Pretoria: Department of Education, Republic of South Africa).

Republic of South Africa, National Treasury Department (2011) National Budget Review - 2011. http://www.treasury.gov.za/documents/national\%20budget/2011/review/excel.aspx (accessed 16 January 2012).

Taylor, N., Fleisch, B, Shindler, J. (2008) Changes in Education since 1994. Background paper for the Fifteen Year Review of government business, commissioned by the Policy Unit, Office of the Presidency. (Johannesburg: Jet Education Services).

Thomas, D. (1996) Education across generations in South Africa. The American Economic Review, 83(2), pp. 330-334. 
Timæus, I. M. and Boler, T. (2007) Father figures: the progress at school of orphans in South Africa. AIDS, 21(suppl 7), pp. S83-S93.

United Nations Development Program (1990) Human and Development Report (New York: Oxford University Press).

van der Berg, S. and Louw, M. (2006) Lessons Learnt from SACMEQII: South African Student Perfomance in Regional Context. Paper presented to the conference on 'Investment Choices for Education in South Africa', Johanesburg, 19-21 September.

van der Berg, S. (2007) Apartheid's enduring legacy: inequalities in education. Journal of African Economics, 16(5), pp 849-880.

van der Berg, S. (2008) How effective are poor schools: poverty and educational outcomes in South Africa. Studies in Educational Evaluation, 34(3), pp. 145-154. 
Table 1. Distribution of school-age children and of their characteristics according to the expenditure quintile of their households

\begin{tabular}{lcccccc}
\hline $\begin{array}{l}\text { Quintile of } \\
\text { household } \\
\text { expenditure }\end{array}$ & $\begin{array}{c}\text { \% distribution } \\
\text { of school-age } \\
\text { children }\end{array}$ & $\begin{array}{c}\text { Mean housing } \\
\text { asset score }\end{array}$ & $\begin{array}{c}\text { Mean durable } \\
\text { asset score }\end{array}$ & $\begin{array}{c}\text { \% suffering } \\
\text { from food } \\
\text { insufficiency }\end{array}$ & \% African & $\begin{array}{c}\text { \% resident in } \\
\text { urban areas }\end{array}$ \\
\hline 1 (lowest) & 40.1 & -1.20 & -1.06 & 32.7 & 97.2 & 31.6 \\
2 & 24.0 & -0.61 & -0.86 & 20.7 & 90.3 & 42.1 \\
3 & 15.4 & 0.21 & -0.49 & 13.5 & 86.3 & 61.8 \\
4 & 11.6 & 0.74 & 0.66 & 9.8 & 73.1 & 83.3 \\
5 (highest) & 8.9 & 1.31 & 2.13 & 1.5 & 37.9 & 94.0 \\
Total & 100.0 & -0.39 & -0.44 & 21.4 & 85.8 & 50.4 \\
\hline
\end{tabular}


Table 2. Percentage of children enrolled in school by age, Living Standards and Development Survey (LSDS), 1993 and National Income Dynamics Study (NIDS), 2008

\begin{tabular}{ccc}
\hline Age & LSDS & NIDS \\
\hline 5 & & 88.8 \\
6 & 74.2 & 97.6 \\
7 & 91.7 & 99.3 \\
8 & 94.0 & 99.1 \\
9 & 96.3 & 98.5 \\
10 & 97.0 & 97.8 \\
11 & 97.1 & 99.1 \\
12 & 97.1 & 98.9 \\
13 & 95.6 & 98.2 \\
14 & 94.4 & 98.3 \\
15 & 90.5 & 97.8 \\
16 & 86.6 & 95.5 \\
17 & 80.7 & 85.6 \\
18 & 66.3 & 75.2 \\
19 & 56.7 & 55.0 \\
20 & 43.5 & 44.8 \\
21 & 34.3 & 32.3 \\
\hline
\end{tabular}


Table 3. Percentage of children having experienced various schooling outcomes by birth cohort or age, National Income Dynamics Study, 2008

\begin{tabular}{lrrr|rr}
\hline Year of birth & $\begin{array}{c}\text { \% enrolled } \\
\text { late }\end{array}$ & $\begin{array}{c}\text { \% repeated } \\
\text { 1+ grades }\end{array}$ & $\begin{array}{c}\text { \% repeated } \\
\text { 2+ grades }\end{array}$ & Age & $\begin{array}{c}\text { \% having } \\
\text { matriculated }\end{array}$ \\
\hline 2001 & 6.7 &.. &.. & 17 & 5.1 \\
2000 & 12.5 & 13.4 &.. & 18 & 17.7 \\
1999 & 13.3 & 18.2 & 2.3 & 19 & 31.2 \\
1998 & 20.4 & 27.9 & 3.5 & 20 & 36.2 \\
1997 & 23.8 & 26.0 & 5.6 & 21 & 43.3 \\
1996 & 17.7 & 28.0 & 7.0 & 22 & 47.6 \\
1995 & 16.0 & 33.3 & 9.5 & 23 & 44.6 \\
1994 & 18.3 & 33.3 & 8.4 & 24 & 40.8 \\
1993 & 24.5 & 35.4 & 11.0 & 25 & 47.0 \\
1992 & 15.8 & 36.5 & 11.4 & 26 & 42.8 \\
1991 & 23.9 & 46.9 & 15.7 & 27 & 37.7 \\
1990 & 12.8 & 51.9 & 20.3 & 28 & 45.6 \\
1989 & 23.7 & 67.2 & 26.4 & 29 & 46.1 \\
\hline
\end{tabular}


Table 4. Relative odds of various schooling outcomes according to the individual's demographic and residential characteristics, National Income Dynamics Study, 2008.

\begin{tabular}{|c|c|c|c|c|c|c|}
\hline & & $\begin{array}{c}\text { Enrolled } \\
\text { late }\end{array}$ & $\begin{array}{l}\text { Repeated } \\
1+\text { grades }\end{array}$ & $\begin{array}{l}\text { Repeated } \\
2+\text { grades }\end{array}$ & & Matriculated \\
\hline \multirow[t]{2}{*}{ Residence } & Rural & 1 & 1 & 1 & & 1 \\
\hline & Urban & $0.71 *$ & $0.73^{* *}$ & $0.57^{* *}$ & & $1.77 * *$ \\
\hline \multirow[t]{9}{*}{ Province } & Western Cape & 0.88 & $0.66^{\dagger}$ & $0.33^{*}$ & & 0.69 \\
\hline & Eastern Cape & 1.42 & $0.59 * *$ & 0.76 & & $0.54 * *$ \\
\hline & Northern Cape & $1.80^{*}$ & 0.79 & 0.89 & & 0.61 \\
\hline & Free State & $0.63^{\dagger}$ & 1.04 & 1.15 & & 1.22 \\
\hline & KwaZulu-Natal & 1 & 1 & 1 & & 1 \\
\hline & North-Western & 0.78 & $0.70^{*}$ & 0.87 & & 1.36 \\
\hline & Gauteng & 0.81 & $0.64 * *$ & $0.53^{\dagger}$ & & 0.83 \\
\hline & Mpumalanga & 0.80 & 1.31 & 1.48 & & 1.03 \\
\hline & Limpopo & $0.41^{* *}$ & $0.73^{*}$ & 1.24 & & 0.75 \\
\hline \multirow[t]{4}{*}{ Race } & African & 1 & 1 & 1 & & 1 \\
\hline & Coloured & $0.62^{\dagger}$ & $0.50^{* *}$ & 1.00 & & 1.03 \\
\hline & Asian/Indian & $0.33^{* *}$ & $0.04^{* *}$ & .. & & 1.29 \\
\hline & White & 0.93 & $0.11 * *$ & $0.07^{*}$ & & $6.18^{* *}$ \\
\hline \multirow[t]{2}{*}{ Sex } & Boys & 1 & 1 & 1 & & 1 \\
\hline & Girls & $0.73^{* *}$ & $0.44^{* *}$ & $0.44 * *$ & & $1.29^{\dagger}$ \\
\hline \multirow[t]{13}{*}{ Year of birth/Age } & 1989 & $1.71 * *$ & $4.76^{* *}$ & $3.84 * *$ & 19 & $0.43^{* *}$ \\
\hline & 1990 & 0.84 & $2.45^{* *}$ & $2.62^{* *}$ & 20 & 0.73 \\
\hline & 1991 & $1.57^{*}$ & $1.72^{* *}$ & $1.72^{*}$ & 21 & 0.90 \\
\hline & 1992 & 1.03 & 1.20 & 1.28 & 22 & 1.00 \\
\hline & 1993 & $1.74^{*}$ & 1.19 & 1.27 & 23 & 0.97 \\
\hline & 1994 & 1.20 & 0.98 & 0.86 & 24 & $0.49 *$ \\
\hline & 1995 & 1 & 1 & 1 & 25 & 0.79 \\
\hline & 1996 & 1.17 & 0.79 & 0.74 & 26 & 0.68 \\
\hline & 1997 & $1.64^{*}$ & $0.69 *$ & $0.57^{\dagger}$ & 27 & $0.43^{*}$ \\
\hline & 1998 & 1.34 & $0.75^{\dagger}$ & $0.34^{* *}$ & 28 & 0.68 \\
\hline & 1999 & 0.84 & $0.42^{* *}$ & $0.22^{* *}$ & 29 & 1 \\
\hline & 2000 & 0.75 & $0.30^{* *}$ & & & \\
\hline & 2001 & $0.37 * *$ & & & & \\
\hline \multicolumn{2}{|c|}{ Number of observations } & 5994 & 7102 & 6429 & & 2151 \\
\hline
\end{tabular}

Note: ${ }^{* *} \mathrm{P}<0.01,{ }^{*} \mathrm{P}<0.05,+\mathrm{P}<0.10$. 
Table 5. Relative odds of various schooling outcomes according to individuals' demographic, residential and socioeconomic characteristics, National Income Dynamics Study, 2008.

\begin{tabular}{|c|c|c|c|c|c|c|}
\hline \multirow{2}{*}{ Residence } & & \multirow{2}{*}{$\begin{array}{c}\begin{array}{c}\text { Enrolled } \\
\text { late }\end{array} \\
1\end{array}$} & \multirow{2}{*}{$\begin{array}{c}\text { Repeated } \\
1+\text { grades }\end{array}$} & \multicolumn{2}{|l|}{$\begin{array}{l}\text { Repeated } \\
2+\text { grades }\end{array}$} & \multirow{2}{*}{$\frac{\text { Matriculated }}{1}$} \\
\hline & Rural & & & 1 & & \\
\hline & Urban & $1.97 *$ & 1.03 & 0.86 & & 1.05 \\
\hline \multirow[t]{9}{*}{ Province } & Western Cape & 0.87 & $0.69^{\dagger}$ & $0.34^{*}$ & & 0.61 \\
\hline & Eastern Cape & $1.50^{\dagger}$ & $0.59 * *$ & $0.71^{\dagger}$ & & $0.43^{* *}$ \\
\hline & Northern Cape & $1.76^{*}$ & 0.86 & 0.85 & & 0.80 \\
\hline & Free State & 0.79 & 1.17 & 1.22 & & 0.89 \\
\hline & KwaZulu-Natal & 1 & 1 & 1 & & 1 \\
\hline & North-Western & 0.97 & 0.88 & 1.10 & & 0.84 \\
\hline & Gauteng & 0.98 & $0.74^{*}$ & 0.69 & & $0.54^{\dagger}$ \\
\hline & Mpumalanga & 1.04 & $1.65^{* *}$ & $1.89 *$ & & 0.70 \\
\hline & Limpopo & $0.57 *$ & 0.97 & $1.58^{*}$ & & $0.55^{\dagger}$ \\
\hline \multirow[t]{4}{*}{ Race } & African & 1 & 1 & 1 & & 1 \\
\hline & Coloured & 0.74 & $0.57 * *$ & 1.24 & & $0.48^{*}$ \\
\hline & Asian/Indian & 1.10 & $0.07 * *$ & .. & & $0.19 *$ \\
\hline & White & $2.08^{*}$ & $0.16^{* *}$ & 0.18 & & $0.37^{\dagger}$ \\
\hline \multirow[t]{2}{*}{ Sex } & Boys & 1 & 1 & 1 & & 1 \\
\hline & Girls & $0.71 * *$ & $0.42 * *$ & $0.42^{* *}$ & & $1.54^{* *}$ \\
\hline \multirow[t]{13}{*}{ Year of birth/Age } & 1989 & $1.45^{\dagger}$ & $4.55^{* *}$ & $3.82^{* *}$ & 19 & $0.27 * *$ \\
\hline & 1990 & 0.78 & $2.46^{* *}$ & $2.67 * *$ & 20 & $0.53^{*}$ \\
\hline & 1991 & 1.47 & $1.66^{* *}$ & $1.73^{*}$ & 21 & 0.78 \\
\hline & 1992 & 1.01 & 1.19 & 1.29 & 22 & 0.86 \\
\hline & 1993 & $1.77 *$ & 1.14 & 1.22 & 23 & 0.84 \\
\hline & 1994 & 1.14 & 0.96 & 0.88 & 24 & $0.43^{*}$ \\
\hline & 1995 & 1 & 1 & 1 & 25 & 0.73 \\
\hline & 1996 & 1.23 & 0.78 & 0.74 & 26 & 0.55 \\
\hline & 1997 & $1.74 *$ & $0.71 *$ & $0.60^{\dagger}$ & 27 & $0.39 *$ \\
\hline & 1998 & 1.39 & 0.76 & $0.35^{* *}$ & 28 & 0.56 \\
\hline & 1999 & 0.89 & $0.42^{* *}$ & $0.23^{* *}$ & 29 & 1 \\
\hline & 2000 & 0.84 & $0.31 * *$ & & & \\
\hline & 2001 & $0.38^{* *}$ & & & & \\
\hline \multirow{5}{*}{$\begin{array}{l}\text { Mother's highest } \\
\text { level of schooling }\end{array}$} & None - Grade 3 & 1 & 1 & 1 & & 1 \\
\hline & Grades 4-6 & $0.72 * *$ & 1.23 & $1.56^{*}$ & & 1.08 \\
\hline & Grades 7-9 & $0.62 * *$ & 0.96 & 1.12 & & $1.77 *$ \\
\hline & Grades 10-11 & $0.43^{* *}$ & $0.82^{\dagger}$ & $0.73^{\dagger}$ & & $2.48^{* *}$ \\
\hline & Matric. or higher & $0.29 * *$ & $0.54 * *$ & 0.75 & & $3.61 * *$ \\
\hline \multicolumn{2}{|c|}{ Housing quality score } & 0.96 & $0.91 * *$ & $0.92^{\dagger}$ & & $1.11^{\dagger}$ \\
\hline \multicolumn{2}{|c|}{ Consumer durables score - rural areas } & $0.53^{* *}$ & \}$\quad 1.01$ & 0.86 & & $1.17^{\dagger}$ \\
\hline \multicolumn{2}{|c|}{ Consumer durables score - urban areas } & $0.90^{*}$ & \} 1.01 & 0.00 & & $1.1 /$ \\
\hline \multicolumn{2}{|c|}{ Children sometimes go to bed hungry } & 1.05 & 1.08 & 1.02 & & $0.73^{*}$ \\
\hline \multicolumn{2}{|c|}{$\ln$ (Expenditure per capita) } & 0.97 & 0.96 & $0.83^{*}$ & & $1.59 * *$ \\
\hline \multicolumn{2}{|c|}{$\ln ($ Expenditure per capita) squared } & $\cdots$ & .. & . & & $1.21 * *$ \\
\hline \multicolumn{2}{|c|}{ Number of young people } & 5990 & 7095 & 6422 & & 2145 \\
\hline
\end{tabular}

Note: ${ }^{* *} \mathrm{P}<0.01,{ }^{*} \mathrm{P}<0.05,{ }^{\dagger} \mathrm{P}<0.10$. 
Table 6. Relative odds of various schooling outcomes according to individuals' demographic, and socio-economic characteristics, cluster fixed effects model, National Income Dynamics Study, 2008.

\begin{tabular}{|c|c|c|c|c|c|c|}
\hline & & $\begin{array}{c}\text { Enrolled } \\
\text { late }\end{array}$ & $\begin{array}{l}\text { Repeated } \\
1+\text { grades }\end{array}$ & $\begin{array}{l}\text { Repeated } \\
2+\text { grades }\end{array}$ & & Matriculated \\
\hline Race & African & 1 & 1 & 1 & & 1 \\
\hline & Coloured & 0.53 & $0.37 * *$ & $0.39^{\dagger}$ & & 0.38 \\
\hline & Asian/Indian & 1.00 & $0.26^{\dagger}$ & .. & & $0.20^{\dagger}$ \\
\hline & White & $0.39^{\dagger}$ & $0.20^{* *}$ & 0.99 & & 0.16 \\
\hline Sex & Boys & 1 & 1 & 1 & & 1 \\
\hline & Girls & $0.68 * *$ & $0.41 * *$ & $0.40^{* *}$ & & $1.49 *$ \\
\hline Year of birth/Age & 1989 & $1.58^{*}$ & $4.79 * *$ & $4.52^{* *}$ & 19 & $0.32^{* *}$ \\
\hline & 1990 & 0.86 & $2.40^{* *}$ & $2.92 * *$ & 20 & 0.63 \\
\hline & 1991 & 1.35 & $1.53^{* *}$ & $1.87^{*}$ & 21 & 0.89 \\
\hline & 1992 & 0.86 & 1.21 & 1.34 & 22 & 1.11 \\
\hline & 1993 & $1.78^{*}$ & 1.14 & 1.28 & 23 & 1.10 \\
\hline & 1994 & 1.35 & 0.97 & 0.91 & 24 & 0.68 \\
\hline & 1995 & 1 & 1 & 1 & 25 & 1.34 \\
\hline & 1996 & 1.19 & 0.78 & 0.79 & 26 & 0.71 \\
\hline & 1997 & $1.53^{\dagger}$ & $0.73^{*}$ & $0.57^{\dagger}$ & 27 & 0.62 \\
\hline & 1998 & 1.40 & $0.76^{\dagger}$ & $0.35^{* *}$ & 28 & 0.91 \\
\hline & 1999 & 0.79 & $0.43^{* *}$ & $0.25^{* *}$ & 29 & 1 \\
\hline & 2000 & 0.75 & $0.30 * *$ & & & \\
\hline & 2001 & $0.35^{* *}$ & & & & \\
\hline Mother's highest & None - Grade 3 & 1 & 1 & 1 & & 1 \\
\hline level of schooling & Grades 4-6 & $0.76^{\dagger}$ & 1.16 & $1.40^{\dagger}$ & & 1.54 \\
\hline & Grades 7-9 & $0.68 * *$ & 0.96 & 1.06 & & $1.90^{*}$ \\
\hline & Grades $10-11$ & $0.44 * *$ & 0.86 & $0.66^{*}$ & & $2.87 * *$ \\
\hline & Matric. or higher & $0.46^{* *}$ & $0.58^{* *}$ & 0.79 & & $2.97 * *$ \\
\hline Housing quality scc & & 0.92 & $0.87 * *$ & 0.91 & & 1.15 \\
\hline Consumer durables & core - rural areas & $0.33^{* *}$ & \} 101 & 1.04 & & 0.95 \\
\hline Consumer durables & core - urban areas & 1.13 & \}$^{1.01}$ & & & \\
\hline Children sometime & go to bed hungry & 1.13 & 1.08 & 1.11 & & $0.69^{\dagger}$ \\
\hline $\ln ($ Expenditure per & apita) & $0.88^{\dagger}$ & 0.94 & $0.78^{* *}$ & & $1.67 * *$ \\
\hline $\ln$ (Expenditure per & apita) squared & & & & & $1.29^{* *}$ \\
\hline Number of observa & ions & 5413 & 6861 & 5264 & & 1807 \\
\hline
\end{tabular}

Note: $* * \mathrm{P}<0.01, * \mathrm{P}<0.05,+\mathrm{P}<0.10$. 